\title{
Basic strategy of tire quality with the epmhasis on the tire industry
}

\author{
Ph. D. Slobodan Stefanović ${ }^{1}$, Ph. D. Vladeta Jevremović ${ }^{2}$, Mr. Nenad Janjić ${ }^{3}$, \\ Msc. Damjan Stanojević ${ }^{4}$, Ph.D. Radoje Cvejic ${ }^{5}$ \\ ${ }^{1}$ Professor, High school for professional applied studies, Vranje, Serbia, \\ ${ }_{2}^{2}$ Professor, High mechanical technical school, Trstenik, Serbia, \\ ${ }^{3}$ Lecturer, High school for professional applied studies, Vranje, Serbia, \\ ${ }^{4}$ Lecturer, High school for professional applied studies, Vranje, Serbia, \\ ${ }^{5}$ Professor, Faculty for strategic and operational management, Belgrade, Serbia,
}

\begin{abstract}
Considering the options for waste rubber - reduction, reuse, recycling, energy recovery and storage in landfills - there is a clear trend towards the renewing of energy. The use of waste tire as an alternative fuel reduces the amount of old tires, protect natural resources and increasing energy independence. In many cases, this is a reasonable option.There are lots of of sustainable options, extensive use of old tire that exist today and that will grow (using rubber granules in retreaded asphalt mixed with caoutchouc to manufacture various rubber products, various applications in the construction industry). Based on the analysis method for recycling rubber products, there is a great diversity in the quality and quantity of recycled material. And it is of primary importance for use in new tires. Methodology production costs optimization, and quality control require further research and efforts to standardize these processes.
\end{abstract}

Keywords: - rubber, tire, recycling, waste.

I. INTRODUCTION - BASICS OD RUBBER THAT IS USED FOR MAKING TIRE

Population growth, rapid industrialization and improved living standards have resulted in an increase in the use of rubber and therefore increasing the amount of waste. Expressed by volume, auto tires are the leading single item of waste.

Around the world rubber consumption is around $18-20 \cdot 10^{6}$ tons through a variety of products. In industrialized countries for the development of the tire leaves $60 \%$ of the total consumption of rubber. Tires are the most famous and the life of the tire is very noticeable. In addition there is a danger of fire from environmental contamination. With the increasing number of cars and bikes vast amounts of waste tires are piling up. On a modern car except tire it is possible to find more than 500 different pieces of rubber, with a total weight range of $30-45 \mathrm{~kg}$. In the U.S., about $242 \cdot 10^{6}$ tires are discarded annually in Canada $20 \cdot 10^{6}$, Germany $60 \cdot 10^{6}$, France $40 \cdot 10^{6}$, UK $45 \cdot 10^{6}$, Italy $39 \cdot 10^{6}$ per year . (Figure 1. ) (1.a). According to the calculations it is generated by the one tire per person per year. In most developed countries, scrap tires are 1-2\% of the total amount of municipal solid waste.

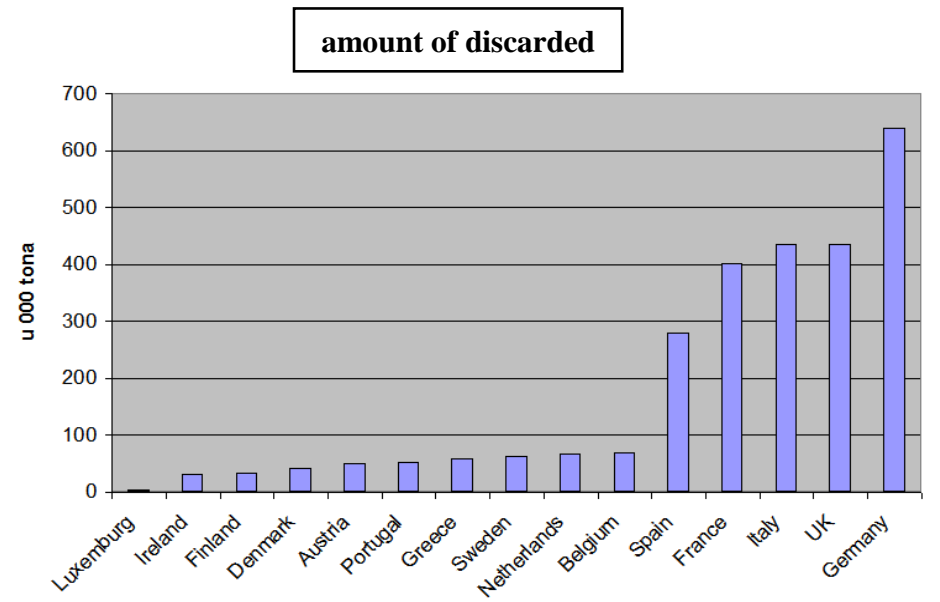

Figure 1. Amount of tire wasted in EU

Estimates are that in Serbia is annually discarded about $1 \cdot 10^{6}, 400$ cars and $400 \cdot 10^{3}$ truck tires, totaling about $30 \cdot 10^{3}$ tons of waste [2]. 
Apart from waste, tire rubber is usually composed of pipes, conveyor belts, the remains of the footwear industry. Other waste rubber parts are made of rubber, washers, insulation material for electrical installations, packaging and others. All this makes smaller share of the total amount of waste.

Recycling is difficult for several reasons:

rubber is a macromolecule which makes difficult degradable 3D network, which prevents the reprocessing,

$>$ rubbers are mixed with incompatible materials and separation is difficult to perform,

$>\quad$ rubber is bio degradable, example- tires are not significantly degraded even after several decades in a landfill.

\section{RUBBER BACKGROUND}

Rubber is a product of natural and artificial materials. Natural rubber is obtained from the milky-white liquid latex, which is obtained from plants. Synthetic rubber is a product derived from unsaturated hydrocarbons.

Long before Columbus' discovery of America, the natives of South America have used rubber for making many waterproof products. The Spanish tried to copy these products ( shoes, coats and cloaks ), but only in the early 18th century, European scientists and industrialists successfully get a tire for commercial use.

British inventor and chemist Charles Macintosh's $1823^{\text {rd }}$ year has introduced at the factory in Glasgow production of rubber canvas and tarpaulin coat. The main breakthrough came in the mid- 19th century with the development process of vulcanization. This process has given increased durability, elasticity and resistance to temperature changes. The resulting rubber is impermeable to gases and resistant to heat, electricity, chemical attack and abrasion.

The main application is vulcanized rubber for tires on vehicles and endless belts, shock absorbers and flexible anti -vibration mounts.

\section{NATURAL RUBBER}

Natural rubber is obtained from rubber plants from the tree Hevea brasiliensis, which originated from South America . Today, more than $90 \%$ of its natural rubber is obtained from trees on its rubber plantations in Indonesia, the Malay Peninsula and Sri Lanka. The common name for all types of rubber is Parrubber. This rubber is extracted from trees in the form of latex. The tree is scratched, slashed diagonally from which is stripped of its bark, where the latex extracts and collects in small containers.

The average annual yield is about $2.5 \mathrm{~kg}$ per tree or $450 \mathrm{~kg}$ per hectare, although only special high-yield trees can give and $3000 \mathrm{~kg}$ per hectare each year. Collected latex was clean, diluted with water and treated with acid in order to stop further coagulation within it. After compaction between rollers to form thin sheets, the rubber is dried in the air and ready for transport. ( Fig. 2)

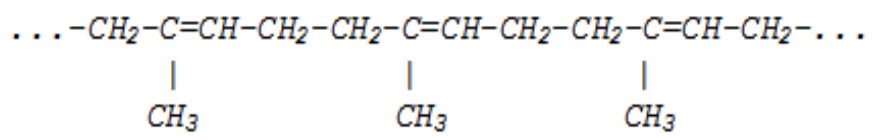

Figure 2. Molecule of natural rubber

\section{SINTETIC RUBBER}

There is a number in the production of synthetic rubbers. They are obtained, such as plastics, as a result of a process called polymerization. These are neoprene, Buna rubber and butyl rubber. Synthetic rubber has been developed with special features for special applications. Synthetic rubber is used for the production of styrene-butadiene or butadiene rubber (Buna, both belonging to the family). Butyl rubber, because it is impermeable to gases, is used for the inner tire. Table 1, shows a typical application of different types of rubber. Raw material for making tire as natural and synthetic rubber, carbon black, cord nylon or polyester, sulfur, tar, oil and more.

In 2005 the world has produced $12 \cdot 10^{6}$ tons of synthetic rubber and $8,8 \cdot 10^{6}$ tons of natural rubber .

The largest producer of natural rubber as Taiwan with $33 \%$, Indonesia $22 \%$, India $9 \%$ and $8 \%$ of Malaysia . The largest manufacturer of synthetic rubber, the U.S. with $26 \%$, followed by Russia with $18 \%$, Japan $15 \%$ and Germany with $5 \%$. About $50 \%$ of the produced rubber is used to manufacture tires. [10] 
Table1 The use of different types of rubber in the manufacture of tires for vehicles

\begin{tabular}{|l|l|}
\hline Type Rubber & Application \\
\hline Natural rubber & $\begin{array}{l}\text { commercial vehicles, trucks, buses , } \\
\text { trailers }\end{array}$ \\
\hline $\begin{array}{l}\text { Styrene - butadiene rubber and } \\
\text { butadiene rubber }\end{array}$ & $\begin{array}{l}\text { trucks,privatecars, motorcycles and } \\
\text { bicycles }\end{array}$ \\
\hline Butyl Rubber & Inner rubbers \\
\hline
\end{tabular}

\section{RUBBER PRODUCTS}

Every year about 16 million tons of natural and synthetic rubber is consumed in the manufacture of products such as medical gloves, tires, bearings, bridges, etc.. The lifespan ranges from a few minutes of medical gloves to more than a century, the bearing bridges.

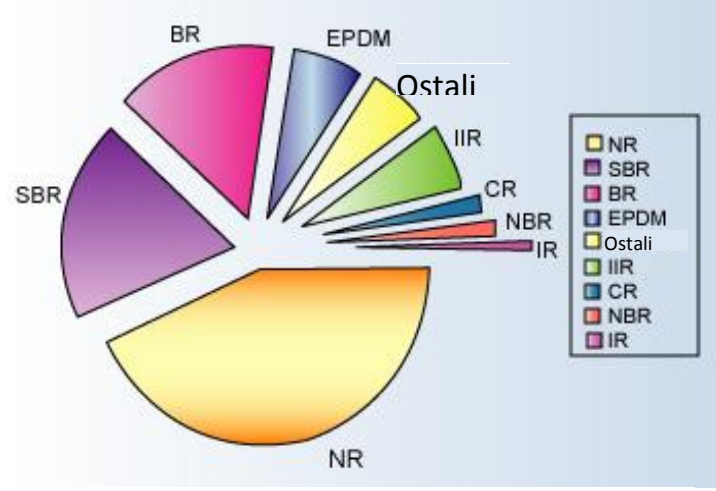

Figure 3 The different types of rubber [4]

Types of rubber depending on the application- Figure 3 shows the proportion of certain types of rubber in industrialized countries:

Two types of rubber, NR and SBR prevalent

$>$ Six frequently used ( BR , IR , IIR , NBR , CR , EPDM ),

$>$ Other special types such as (CSM, CPE, FKM, FFKM, silicones, CO, ECO, ACM, etc) have a very specific application.

Rubber itself is not suitable for industrial use.

Tires - are a complex composite material. They consist of (Figure 4 ) : natural rubber ( $17 \%$ weight), synthetic rubber ( about $31 \%$ ), black ( $22 \%$ ), steel cord $(15 \%)$, textile cord (about $5 \%$ ) and different additive ( about $10 \%)$.

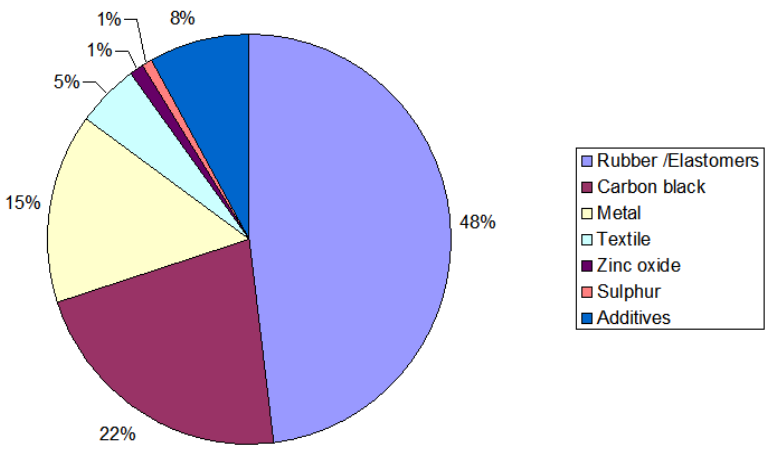

Figure 4. The composition of tire thetireautomobila

Rubber goods can be divided into two categories:

Tires : manufactured about $250 \cdot 10^{6}$ pieces in Europe every year, and that is more than $2,6 \cdot 10^{6}$ a with century exploatation of several years , 
Industrial products: various sizes and total weight of discarded industrial rubber products is greater than $3 \cdot 10^{6}$ tons. Industrial rubber products are difficult or impossible to collect. Rubber products are very heterogeneous :

- According to the dimensions, weighing less than a gram to the tone, the length of a millimeter up to hundreds of meters or even kilometers in endless belts,

- A variable life span, from a few minutes up to more than a century.

\section{BARIERS TO RECYCLING TIRES}

Perturbation for recycling tires: immutable three-dimensional network

Rubber elasticity is the result of a 3D network, during vulcanization occurs connecting of the macromolecules of the original rubber. Chemical bonds between linear macromolecules also prevent relative movement.

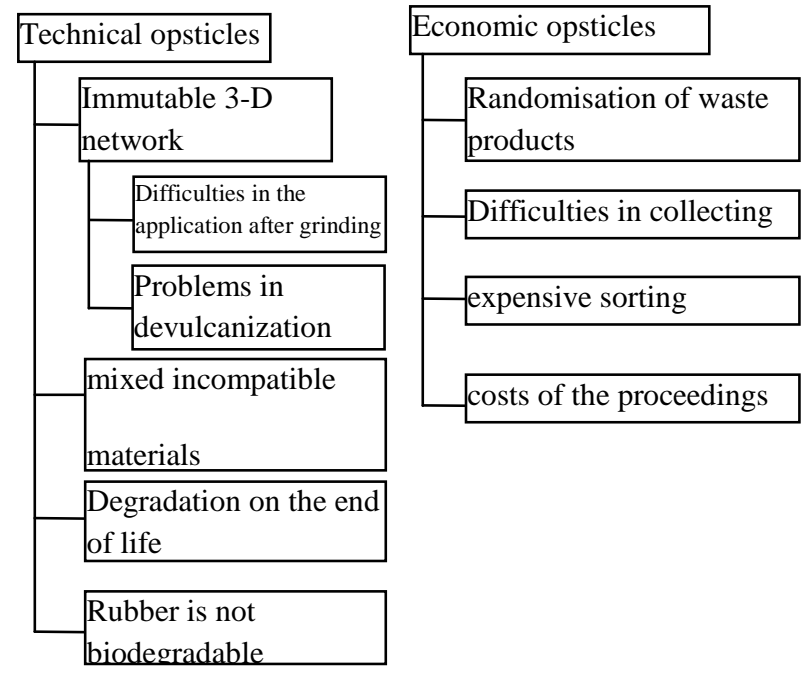

Figure 5.Difficulties in recucling tires [4]

\subsection{Rubber is biodegradable}

Rubbers are not subject to the degradation of nature and the tires do not decompose after burying in landfills after a few decades. Other ways of degradation, photolysis or hydrolysis, they too slow and limited to the surface layers.

Tires are manufactured so that they are sturdy and long-lasting. Rubber is spatially cross-linked elastomeric. Networking covers all the reactive centers of the polymer chains. Cross linked structure is a major problem for the recycling of tires.

\subsection{Mixing of incompatible materials}

Products such as steel / rubber parts, belts, reinforced hose, wrap the rolls, coated materials, adhesive insulating tape, systematically include gain or other incompatible materials such as steel, thread, cloth, plastic coating and the like. Joining is strong and separation is difficult and expensive. There are industrial processes for the separation of tires and other rubber material but generally is mechanically destroyed and can be re-used in the vulcanization or a powder.

\section{WORKMANSHIP OF RUBBER PRODUCTION - TIRE}

Modern tire production process is performed in a complex series of processes such as crushing, mixing, forming , fabrication and vulcanization in a mold . Various additives are added during the mixing process in order to obtain appropriate characteristics of the finished product .

Additives include :

- Polymers,

- rubber accelerators ,

- activators ,

- vulcanizing agents ,

- fillers (carbon black),
- flame retardants,

- anti - degradante,

- dyes and pigments,

- softener 
Fillers are used for curing and reinforcing rubber.

Soot is anti abrasive and is commonly used in the manufacture of tires. Dyes include zinc oxide, Lithopone (a mixture of barium sulfide and zinc sulfide), and organic dyes.

Plasticizers, which are necessary for a proper mixture of dense incorporating various ingredients, were produced from oil, such as paraffin or oil, coal tar or a fatty acid. Processes the mixture was made into a mold, and vulcanization is carried out while the product is in the mold.

Table 2. The composition of the passenger and freight tire in $\%$

\begin{tabular}{|l|c|c|}
\hline Material & Cargo Freight & Freight tire \\
\hline Rubber & 48 & 43 \\
\hline Soot & 22 & 21 \\
\hline Steel & 15 & 27 \\
\hline Textiles & 5 & - \\
\hline Zinc oxide & 1 & 2 \\
\hline Sulfur & 1 & 1 \\
\hline Other accessories & 10 & 6 \\
\hline
\end{tabular}

VIII. VULCANIZATION

The crude latex was composed of a very large number of long, flexible molecular chains. These chains are joined together so as to prevent lateral movement of molecules, it takes on the elastic properties of rubber .

Bonding process is carried out by heating the latex and sulfur (vulcanization other means such as selenium and tellurium are used sometimes but sulfur is mostly in use) (Figure 6) .

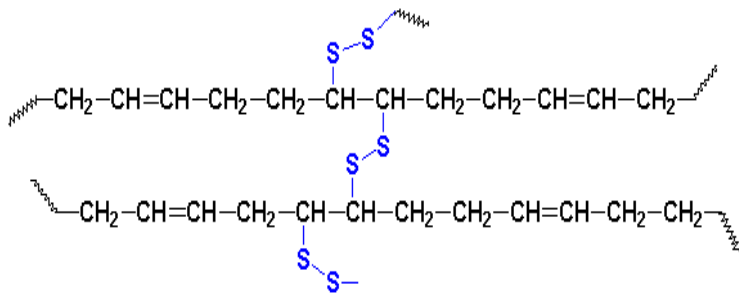

Figure 6. Molecules linked rubber molecules sulfur
Tread

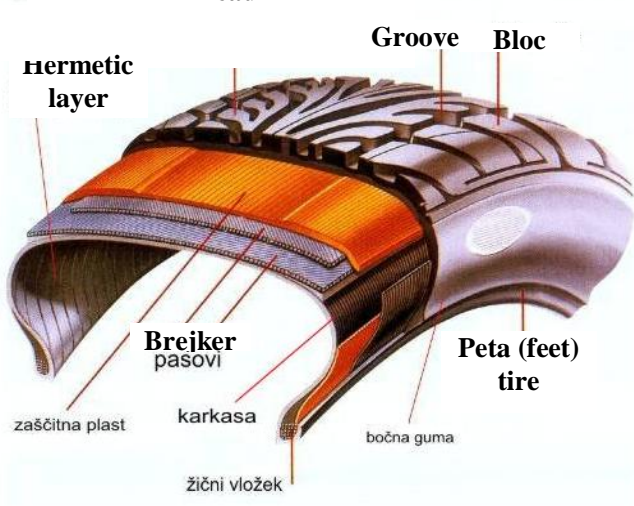

Figure 7. Tire structure

There are two types of vulcanization process.

1. Vulcanization under pressure - the process is done by preheating rubber and sulfur under pressure and at a temperature of $150 \mathrm{OC}$. Many products are obtained by vulcanization - in to the lens of which is compressed with the help of hydraulic presses.

2. The free vulcanization - when it is not possible to provide the pressure for the vulcanization, as was the case with continuous, extruded products, vulcanization is carried out by applying hot air or steam. Some type of garden hose, for example, a coating and vulcanization is carried out by passing steam through the high pressure hose.

\section{TYRE STRUCTURE}

No matter what the type of tire works, the structure of tires makes [5] (Figure 7):

$>$ Tread (protector) - the outer part of the tire that is in constant contact with the ground. Made of sturdy rubber resistant to abrasion, and profiled (patterned ) under the terms and manner of exploitation of a particular model of tire,

$>$ The groove profile and block profile (pattern tire) - channels which intersected protector. Channels are used for drainage and provide better traction on wet surfaces ,

$>$ Hermetic layer - the inner rubber layer, especially for tubeless tires, due to their tightness, has a duty to maintain the internal pressure,

$>$ fifth ( rate ) tire - thickened rim reinforced with multiple coils of steel wire, mutually isolated, which abuts the wheel ( rim ) and provides adhesion and sealing tires, 
$>$ The side wall - the side of the tire. Thinner than a protector and sensitive to damage. It contains all the necessary codes,

$>$ Carcass - or body of the tire is a fundamental part of the tire. It consists of several layers of fabric, which can be made of different types of fibers (Cord). Provides the necessary strength, suppleness and elasticity,

> Cord - rubberized cloth fibers that make up the carcass. Can be textiles, viscose, polyamide or steel. Vulcanization process, fiber cords are rubber and glued to each other,

$>$ Breaker - two or more layers of rubberized cord, extensive set below the tread. The role is to further strengthen the shell and the tread portion, which especially in the radial tire, gets much of the driving characteristics tire

$>$ Radial tire - tire types in which the casing or coiled cord radically from edge to edge of the tire ,

$>$ Diagonal tire - tire types in which the casing or coiled cord diagonally at an angle of 30-40 degrees to the longitudinal axis of the tire.

\section{$X$ CLASSIFICATION OF USED TIRES - TIRES}

Used tires are classified in the following main types:

- The used tire that can be used for their original purpose. This tire is called the used tire (tire). The tire can be reused because the tread is partially depleted (thin), and the other parts of (hi, rate, carcass, breakers hermetic layer) preserved, to the extent that it can be safely used on vehicles. Used tire (tire) must comply with the regulations for the use of tires on the roads in a particular country. Some countries have regulations regarding the minimum preservation of the parts of tires, particularly tire tread, i.e. Minimum depth "Bootleg."

- The used tire that can not be used for their original purpose but is suitable for so-called. retreading. The tire can not be reused because the tread is too worn (thin), but if other parts preserved, can be applied (vulcanization) new tread that. "Sara" and it can be safely used on vehicles.

- Used tires that can not be used for their original purpose and is not suitable for retreading, treated as waste tires.

The above mentioned classification is normally accepted by the EU.

\section{RECYCLING AND RECOVERY TIRE - ALTERNATIVE}

Over the last ten years in the world is growing interest in recycling tires. When it comes to tires, the term "recycling" is misused. The exact definition of recycling is reuse of material in its original purpose. The term recycling tires include the operations of comminuting and grinding waste with adoration metals, textiles and other impurities present in order to obtain the rubber granules.

\section{USE OF RECYCLED MATERIAL FOR NEW TIRES}

At the beginning of the 80s of XX century, there is certain technological and commercial success in the use of recycled rubber products. However, the use of recycled rubber in new tires were slow due to a number of technological and economic constraints that results from differences between the chemical and manufacturing methods used in the manufacture of tires .

Get recycled rubber from waste tire is pretty hard, tires contain more than one compound of rubber, then steel wire, textile cord, fiberglass, and plastic fibers. The process of recycling involves separating the steel cord and textile fibers, rubber through the multi-step process and the use of expensive equipment.

Table 3. The main ways in recycling tire process

\begin{tabular}{|c|c|c|}
\hline Certain species recovery & & Technology renewal \\
\hline \multirow[b]{2}{*}{ Reuse of products } & Regeneration & $\begin{array}{l}\text { - } \quad \text { tire with a new tread }(5-12 \% \text { of waste tires } \\
\text { and truck tires } 50 \%) \\
\text { grooving profile }\end{array}$ \\
\hline & Physical reuse & $\begin{array}{ll}- & \text { used as a weight } \\
- & \text { used as a form of } \\
- & \text { use the properties } \\
- & \text { use the volume }\end{array}$ \\
\hline \multirow{3}{*}{ Reuse of materials } & Physical & $\begin{array}{ll}\bullet & \text { tear } \\
\bullet & \text { cutting } \\
\bullet & \text { crushing the crumbs }\end{array}$ \\
\hline & Chemical & reclamation \\
\hline & Thermal & $\begin{array}{ll}\bullet & \text { pyrolysis } \\
\bullet & \text { combustion } \\
\end{array}$ \\
\hline Getting energy & & - $\quad$ incineration \\
\hline
\end{tabular}




\section{STRATEGIES OF USING SCRAP TIRES}

The following strategies are recommended as optimal for the recycling of waste tire:

$>$ Reduction of waste generation ,

$>$ Repair and reuse ( retreading - applying a new layer of rubber compounds in the tire surface, tapping new profile )

$>$ Reuse of whole tire (artificial reefs, erosion control barriers, buffers )

$>$ Chemical degradation - various forms devulcanization,

$>$ Reduce the use of new raw materials - the return of natural materials to create new products (natural and synthetic rubber, carbon black, fabric and steel wire )

$>$ Energy recovery - getting fuel from the tires (TDF ),

$>$ Shredding and storage.

\section{CONCLUSION}

Million tons of tire recycling of end of life as well as industrial tires is a big problem.

Today in Europe, the total amount of rubber waste:

$>$ One-third of the waste tire is located in warehouses, and the tire is not subject to biodegradation,

$>$ Reuse and retreading is used by $20-25 \%$

$>$ Recycling of various materials use is about $20 \%$,

$>$ Recovery of energy use is about $22 \%$,

$>$ Recycling of industrial rubber products is unknown, but very poorly.

Based on the review of reference journals, publications, bibliographic data, internet sites, where the focus was on methods, processes and technology to dispose of waste rubber, it was noted:

1. In industrialized countries, the advanced technologies have been adopted and are usually supported by the state for environmental reasons. Adopted are economically viable and commercially viable alternatives based on environmental regulations,

2. Based on available tools, equipment, machinery and labor, cheaper technologies used in developing countries,

3. Increase advertising of products produced from waste tires. In the answers - probably escape legislation to impose recycling, reuse and resource conservation,

4. It is necessary to carry out the assessment and monitoring of the environmental effects of recycling processes, products and working conditions,

5. Form technical advisory services to small businesses for recycling in order to improve the technology for recycling

6. Provide public education and awareness of knowledge about the importance of recycling,

7. Conduct research in order to prolong the lifetime of the tire modification of tire construction, switching to radial technology and using quality materials to produce .

\section{Journal Papers:}

\section{REFERENCES}

[1] Rohlwing K., Tire Fees and Recycling: How Does Your State Compare? Editor and TIA Senior Vice President of Education and Technical Services, July/August 2005, Today's Tire Industry.

[2] Pilić, B., Odbačena pneumatika - ekološka katastrofa ili dragocena sirovina, // II Kongres inženjera plastičara i gumara, YU POLIMERI 2002, Čačak 28-31. 05. 2002. god. OS1 - OS4.

[3] Milosavljević, Dj. et. all, Valorizacija otpada iz proizvodnje gumeno-tehničke robe na bazi EPDM i butadien nitrilnog kaučuka, I Jugoslovenski kongres plastičara i gumara PLASTIGUM 93, Vrnjačka Banja, 27-29. 04. 1993. str 79-81.

[4] S. STEFANOVIĆ, V. JEVREMOVIĆ, D. STANOJEVIĆ, CONDITIONS FOR INCREASING THE RECYCLED CONTENT IN NEW TIRES FROM ASPECT OF INCREASING THEIR QUALITY, Tome XI (Year 2013). Fascicule 3. str. 23-28, ISSN 1584 - 2665, ANNALS of Faculty Engineering Hunedoara, Romania

Books:

[5] Urek, A., Pomen reciklaže avtopnevmatik, Specijalistično delo, Ljubljana, Ekonomski fakultet, 2005.

[6] Zanetti, M. C., Genon, G., Recycle of Used Tyres: Criogenic Disintegration and Reuse of The Obtained Products, Polytechnic of Turin-Diget, Italy. 
[7] Capelle, G., Nova saznanja kod materijalnog korišćenja auto-guma, upotrebljenih gumenih proizvoda i gumenog otpada, Hermann Berstorff GmbH, Hannover, Germany.

[8] M. Pantelić, S. Stefanović, D. Golubović, EKOLOŠKI PROBLEMI I ZAŠTITI ŽIVOTNE SREDINE, Čačak, 2010.

[9] R. Cvejić, S. Stefanović, EKOLOŠKI MENADŽMENT, Visoka poslovna škola za biznis, Beograd, 2009.

Theses:

[10] V. Jevremović, IZBOR TEHNOLOŠKE STRATEGIJEZA RECIKLAŽU PROIZVODA OD GUME Doktorska disertacija, Fakultet tehničkih nauka, Novi Sad, 2007.

\section{Proceedings Papers:}

[11] www.etra-eu.org

[12] www.BankReferatov.ru

[13] Manić, D., Korišćena guma kao sekundarna sirovina (Preuzeto iz TIGAR info, list TIGAR AD)// Svet polimera 5 (4), 2002, str. 214.

[14] http://www.tigar.co.yu 